WSRC-STI-2008-00260

Revision 0

\title{
SALTSTONE CY07 TCLP RESULTS
}

\section{A.D. Cozzi}

June 2008

Environmental \& Chemical Process Technology Savannah River National Laboratory

Aiken, SC 29808

Prepared for the U.S. Department of Energy Under Contract Number DEAC09-96SR18500

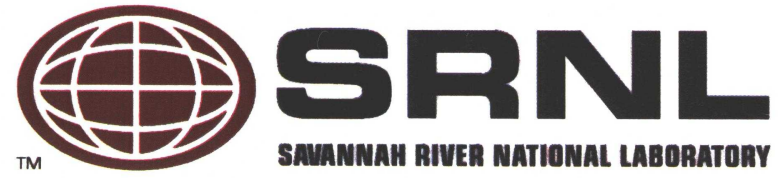


WSRC-STI-2008-00260

Revision 0

\section{DISCLAIMER}

This report was prepared by Westinghouse Savannah River Company (WSRC) for the United States Department of Energy under Contract No. DE-AC09-96SR18500 and is an account of work performed under that contract. Neither the United States Department of Energy, nor WSRC, nor any of their employees makes any warranty, expressed or implied, or assumes any legal liability or responsibility for the accuracy, completeness, or usefulness, of any information, apparatus, or product or process disclosed herein or represents that its use will not infringe privately owned rights. Reference herein to any specific commercial product, process, or service by trademark, name, manufacturer or otherwise does not necessarily constitute or imply endorsement, recommendation, or favoring of same by WSRC or by the United States Government or any agency thereof. The views and opinions of the authors expressed herein do not necessarily state or reflect those of the United States Government or any agency thereof.

\section{Printed in the United States of America \\ Prepared For \\ U.S. Department of Energy}


WSRC-STI-2008-00260

Revision 0

Key Words: Saltstone

TCLP

Retention: Permanent

\section{SALTSTONE CY07 TCLP RESULTS}

\section{A.D. Cozzi}

June 2008

Environmental \& Chemical Process Technology Savannah River National Laboratory

Aiken, SC 29808

Prepared for the U.S. Department of Energy Under Contract Number DEAC09-96SR18500

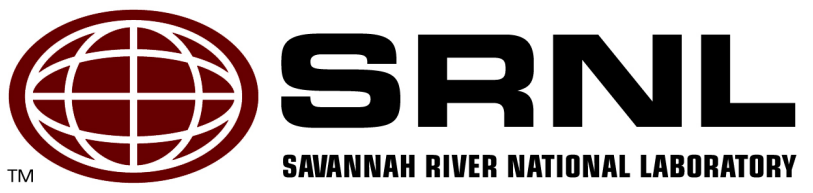




\section{REVIEWS AND APPROVALS}

\section{AUTHORS:}

A.D. Cozzi, Stabilization Science Programs

Date

\section{TECHNICAL REVIEWER:}

R.E. Eibling, Engineering Process Development

Date

\section{APPROVERS}

J. C. Griffin, Manager, E\&CPT Research Programs

Date

D. A. Crowley, Manager, Stabilization Science Programs

Date

J. E. Occhipinti, Manager, Waste Solidification Engineering

Date 


\subsection{EXECUTIVE SUMMARY}

Saltstone waste forms were prepared in the Savannah River National Laboratory from Tank $50 \mathrm{H}$ samples and Z-Area premix material for each of the four quarters of calendar year 2007 (CY07). After the prescribed 28 day cure, samples of the saltstone were collected, and the waste form was shown to meet the South Carolina Hazardous Waste Management Regulations (SCHWMR) R.6179.261.24 and R.61-79.268.48(a) requirements for a nonhazardous waste form with respect to RCRA metals and underlying hazardous constituents. These analyses met all quality assurance specifications of USEPA SW-846. 


\section{TABLE OF CONTENTS}

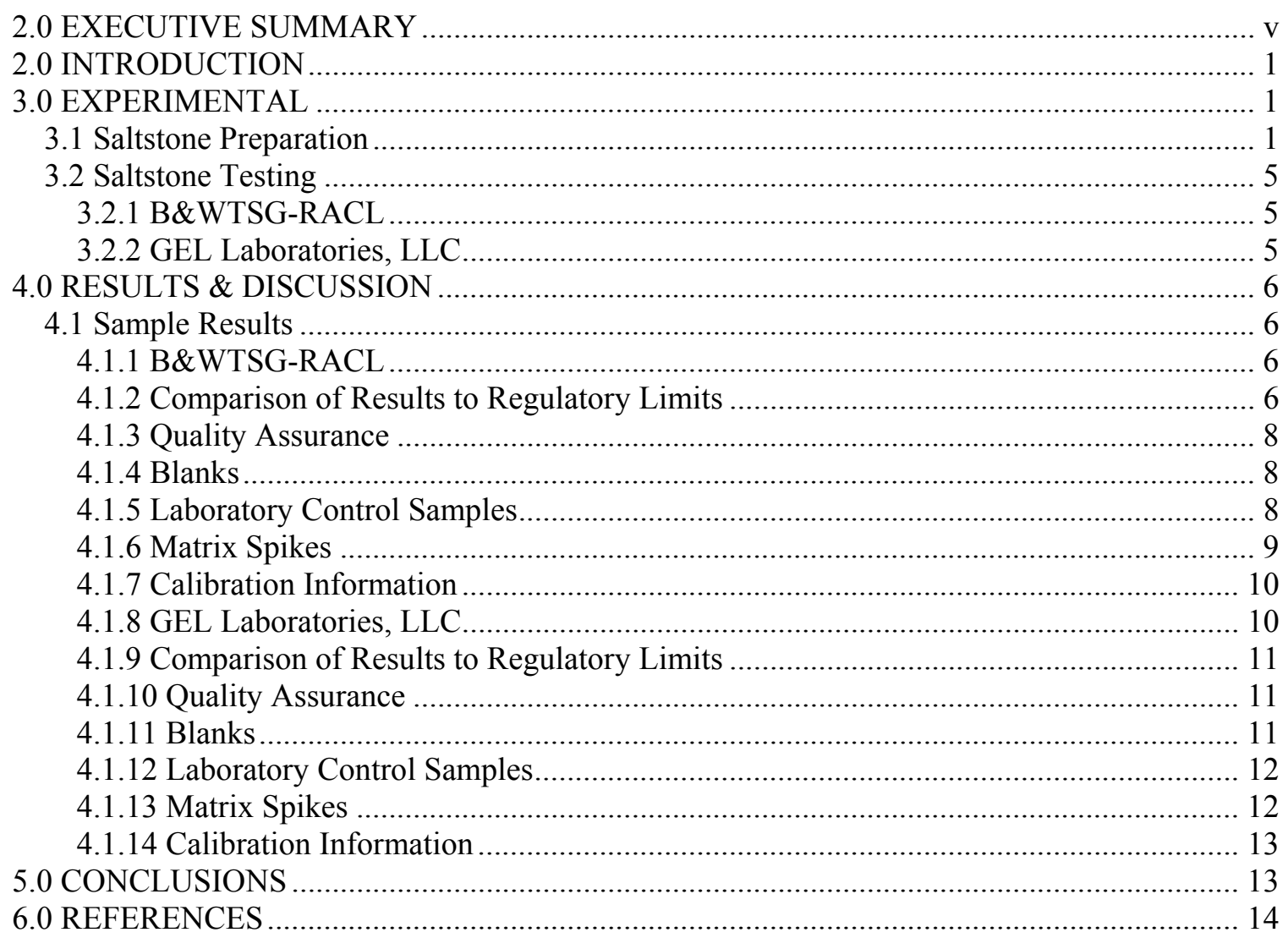




\section{LIST OF FIGURES}

Figure 1 Flowchart of saltstone sample preparation and analysis............................................ 1

Figure 2. Data sheets for the saltstone mixes used to prepare samples for TCLP......................... 4 


\section{LIST OF TABLES}

Table 1. Sample Results of TCLP Metal from Tank 50 WAC Analyses...................................... 2

Table 2. Customer Recommended Values for Preparation of TCLP Samples............................... 3

Table 3. TCLP Leachates RCRA Metal Concentrations, DLs, and QLs. ...................................... 6

Table 4 Saltstone TCLP Results and Corresponding Regulatory Limits. ..................................... 7

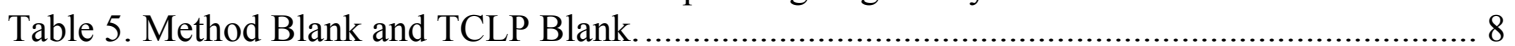

Table 6. RCRA Metal Laboratory Control Sample.......................................................... 9

Table 7. TCLP Leachates RCRA Metal Matrix Spike and Duplicate Results. ........................... 10

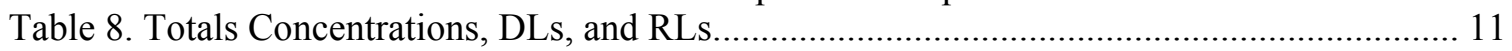

Table 9 Saltstone Totals Results and Corresponding Regulatory Limits.................................... 11

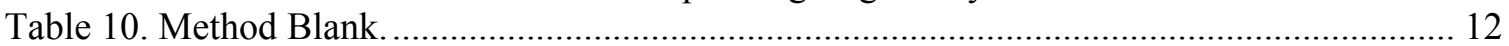

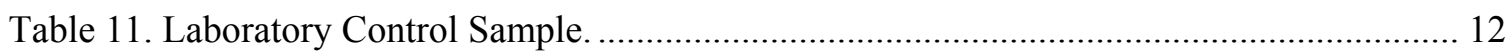

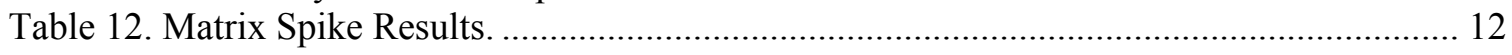




\section{LIST OF ACRONYMS}

B\&WTSG- $\quad$ B \& W Technical Services Group-Radioisotope and Analytical Chemistry Laboratory

RACL

CVAA Cold Vapor Atomic Absorption

DL Detection Limit

ESS-WP Environmental Services Section - Waste Programs

ETP Effluent Treatment Project

ICP-MS Inductively Coupled Plasma - Mass Spectrometer

ISWLF Industrial Solid Waste Landfill

LCS Laboratory Control Sample

MCL Maximum Contaminant Level

MS Matrix Spike

MSD Matrix Spike Duplicate

QL Quantitation Limit

RCRA Resource Conservation and Recovery Act

RL Reporting Limit

RPD Relative Percent Differences

SCDHEC South Carolina Department of Health and Environmental Control

SDF Saltstone Disposal Facility

SDG Sample Delivery Group

SPF Saltstone Production Facility

SRNL Savannah River National Laboratory

TCLP Toxic Characteristic Leaching Procedure

UHC Underlying Hazardous Constituent

UTS Universal Treatment Standards 


\subsection{INTRODUCTION}

The Saltstone Production Facility (SPF) receives waste from Tank 50H for treatment. In the 2007 calendar year (CY07), in addition to the H-Canyon low-activity waste and Effluent Treatment Project (ETP) waste that comprised Batch 0, which was processed for disposal in the Saltstone Disposal Facility (SDF) from 12/04/2006 through 02/13/2007, Tank 50H received a significant waste transfer from Tank $23 \mathrm{H}$ and a smaller transfer from Tank $49 \mathrm{H}$.

The Saltstone Grout Sampling plan provides the South Carolina Department of Health and Environmental Control (SCDHEC) with the chemical and physical characterization strategy for the salt solution which is to be disposed of in the Z-Area Industrial Solid Waste Landfill (ISWLF) during CY07 processing. During operation, samples were collected from Tank $50 \mathrm{H}$ and grout samples prepared to determine the non-hazardous nature of the grout to meet the requirements of SCHWMR R.61-79.261.24(b) and R.61-79.268.48(a). ${ }^{1}$

SRNL was asked to prepare saltstone from a sample of Tank $50 \mathrm{H}$ obtained during CY07 processing to determine the non-hazardous nature of the grout. The samples were cured and shipped to Babcock \& Wilcox Technical Services Group-Radioisotope and Analytical Chemistry Laboratory (B\&WTSG-RACL) to perform the Toxic Characteristic Leaching Procedure (TCLP) ${ }^{2}$ and subsequent extract analysis on saltstone samples for the analytes required for the quarterly analysis saltstone sample. In addition to the eight toxic metals - arsenic, barium, cadmium, chromium, mercury, lead, selenium silver-analytes included the underlying hazardous constituents (UHC) beryllium, nickel, and thallium which could not be eliminated from analysis by process knowledge. ${ }^{3}$ B\&WTSG-RACL provided subsamples to GEL Laboratories, LLC for analysis for benzene, phenols and total and amenable cyanide. 
WSRC-STI-2008-00260

Revision 0

\subsection{EXPERIMENTAL}

This section is a summary of the approach taken to prepare and characterize the saltstone samples. The saltstone sample preparation was performed in SRNL. Saltstone sample characterization was performed at both B\&WTSG-RACL facility in Lynchburg, Virginia and the GEL laboratory facility in Charleston, South Carolina. Figure 1 is a flowchart of the steps taken to prepare and characterize the saltstone samples.

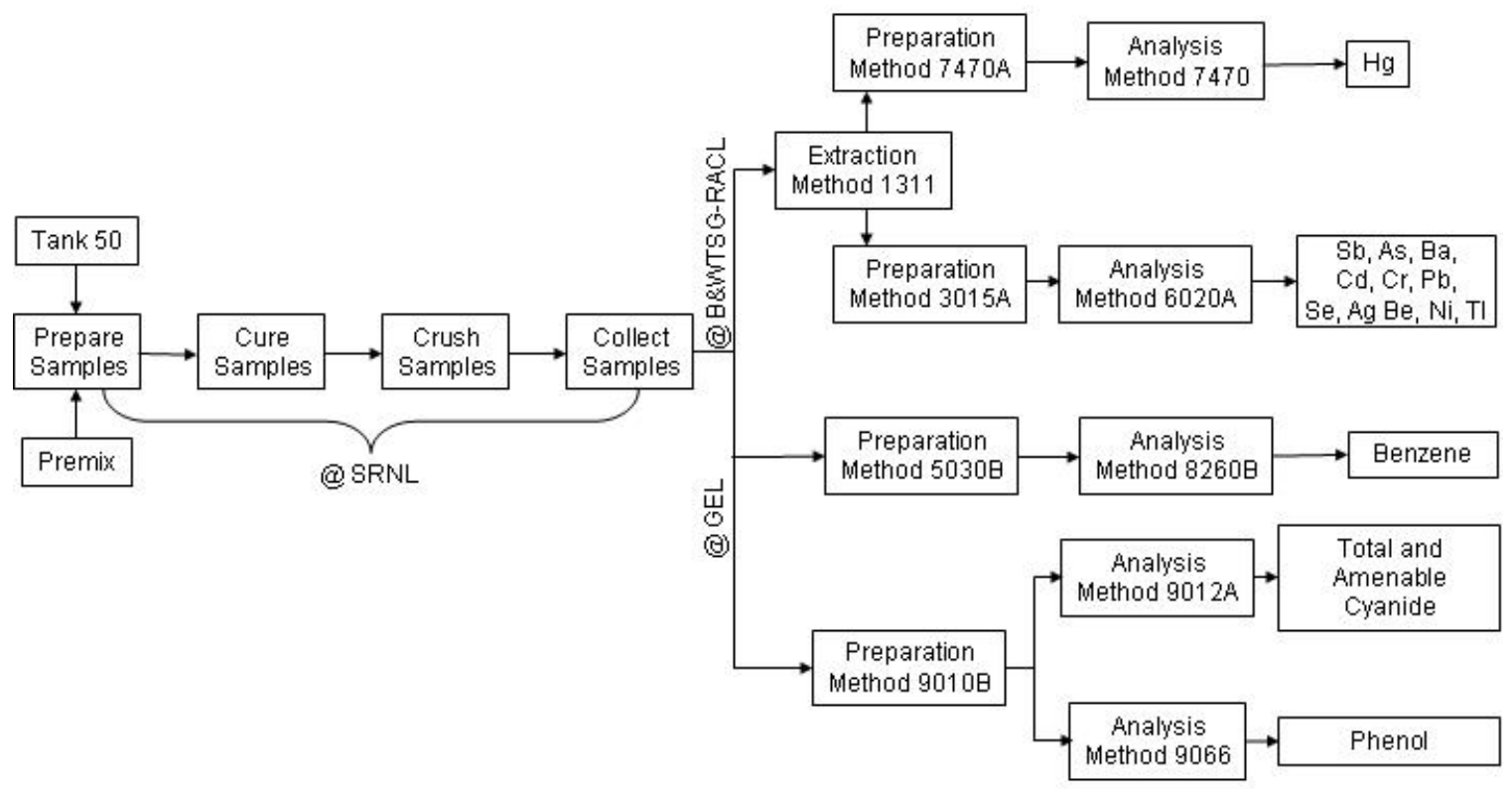

Figure 1 Flowchart of saltstone sample preparation and analysis.

\subsection{Saltstone Preparation}

Saltstone preparation was performed at SRNL. The weight percent solids data used for the TCLP samples were taken from the quarterly Waste Acceptance Criteria (WAC) analyses performed on Tank 50.-7 Table 1 lists the concentration TCLP metals of interest in the salt solution from the WAC analyses from the samples taken in 2007. Complete analyses of the salt solution used are in References 2-5. Table 2 contains the parameters used to prepare each of the TCLP samples.

Saltstone samples for TCLP were prepared with the Tank $50 \mathrm{H}$ blended salt solution and a premix of cement, slag, and fly ash. Figure 2 shows the formulation used to prepare these samples. The salt solution, admixtures and premix materials were combined in a blender and mixed at low speed for one minute, inspected for incorporation of the premix, and then mixed at high speed for an additional two minutes. After the saltstone slurry was mixed, it was cast into glass bottles with Teflon lined lids to cure.

After curing for not less than 28 days, ${ }^{*}$ the saltstone was removed from the container and a portion of the saltstone was crushed to particles less than 0.9 centimeters $(3 / 8$ inch) as prescribed by Section 7.13 of the TCLP method. ${ }^{2}$ The crushed saltstone was packaged into containers provided by Environmental Services Section - Waste Programs (ESS-WP). After the saltstone has been crushed, sieved and packaged, the sample is deemed "collected." ${ }^{8}$ ESS-WP retrieved the samples from SRNL and transported them to B\&WTSG-RACL for extraction and analysis.

* Samples are considered ready for analysis after 28 days. Samples are not crushed until shipment has been scheduled. 
B\&WTSG-RACL repackaged 9-10 grams of each of the four samples and shipped the samples to GEL Laboratories to perform totals analysis for the UHCs benzene, phenol and total and amenable cyanide.

Table 1. Sample Results of TCLP Metal from Tank 50 WAC Analyses.

\begin{tabular}{|c|c|c|c|c|c|}
\hline \multirow[b]{2}{*}{-} & \multicolumn{4}{|c|}{$\begin{array}{c}\text { Sample Results } \\
(\mathrm{mg} / \mathrm{L})\end{array}$} & \multirow{2}{*}{$\begin{array}{c}\begin{array}{c}\text { Regulatory Limits } \\
\text { (mg/L) }\end{array} \\
\text { Toxicity }^{\mathrm{a}}\end{array}$} \\
\hline & $1 Q 07^{4}$ & $2 Q 07^{5}$ & $3 Q 07^{6}$ & $4 \mathrm{Q}^{0} 7^{7}$ & \\
\hline As & $<0.715$ & $<0.061$ & $<0.0535$ & $<0.0463$ & 5 \\
\hline $\mathbf{B a}$ & $<10.7$ & 1.56 & $<1.23$ & 1.91 & 100 \\
\hline Cd & $<3.98$ & $<0.304$ & $<1.6$ & $<1.39$ & 1 \\
\hline $\mathrm{Cr}$ & $<20.4$ & 15.3 & 11.5 & 14.9 & 5 \\
\hline $\mathbf{P b}$ & $<253$ & 1.44 & 0.879 & 1.93 & 5 \\
\hline Hg & 6.93 & 68.3 & 26.0 & 101 & 0.2 \\
\hline Se & $<1.43$ & $<0.122$ & $<0.107$ & $<0.0926$ & 1 \\
\hline Ag & $<8.7$ & $<0.719$ & $<0.568$ & $<4.90$ & 5 \\
\hline-- & -- & -- & -- & -- & $\mathbf{U H C}^{\mathbf{b}}$ \\
\hline Be & NM & $<1.59 \mathrm{E}-02$ & $<0.217$ & $<0.187$ & 1.22 \\
\hline $\mathbf{N i}$ & $<29.6$ & 43.3 & 16.2 & 37.4 & 11 \\
\hline $\mathbf{T l}$ & NM & 0.464 & $<2.63 \mathrm{E}-04$ & 0.134 & 0.20 \\
\hline - & - & - & - & - & $(\mathrm{mg} / \mathrm{kg})$ \\
\hline benzene & $<0.25$ & $<0.25$ & $<0.25$ & $<0.25$ & 10 \\
\hline phenol & $<1$ & $<0.1$ & 1.5 & $<0.1$ & 5.2 \\
\hline $\begin{array}{c}\text { cyanide } \\
\text { (total) }\end{array}$ & NM & $\mathrm{NM}$ & NM & $\mathrm{NM}$ & 1.2 \\
\hline $\begin{array}{c}\text { cyanide } \\
\text { (amenable) }\end{array}$ & NM & NM & $\mathrm{NM}$ & NM & 0.86 \\
\hline
\end{tabular}

NM - Not Measured

${ }^{a}$ R.61-79.261.24(b) "Characteristic of Toxicity."

${ }^{\mathrm{b}}$ R.61-79.268.48 "Universal Treatment Standards." 
WSRC-STI-2008-00260

Revision 0

Table 2. Customer Recommended Values for Preparation of TCLP Samples.

\begin{tabular}{|c||c|c|c|c|}
\hline Parameter & $\mathbf{1 Q 0 7}$ & $\mathbf{2 Q 0 7}$ & $\mathbf{3 Q 0 7}$ & $\mathbf{4 Q 0 7}$ \\
\hline \hline Water-to-Premix ratio & 0.63 & 0.63 & 0.62 & 0.62 \\
\hline Set Retarder g/g premix & 0.27 & 0.27 & 0.27 & 0.19 \\
(Daratard 17) gal/Ton premix & 0.53 & 0.53 & 0.53 & 0.37 \\
\hline Defoamer g/g premix & 0.14 & 0.14 & 0.066 & 0.066 \\
(Clean Air 100) gal/Ton premix & 0.35 & 0.35 & 0.16 & 0.16 \\
\hline
\end{tabular}

As can be gleaned from Table 1, mercury and chromium are the two constituents positively identified above toxic levels. The analyses of the constituents shaded in gray were reported with detection limits greater than the toxicity limit and therefore must be considered toxic for those constituents. Because the samples are considered hazardous, treatment is required for the UHCs nickel and thallium, as they exceed the regulatory limits as shown in Table 1. For the 2Q sample, SRNL Analytical Development was asked to reduce the detection limit to below the toxicity level. This was accomplished for all constituents but cadmium. To determine if a TCLP is required, the maximum release can be calculated from the contaminant level in the waste solution, normalized to the concentration in saltstone, and multiplied by twenty to account for the TCLP extract. For example, from Table 1, the concentration of cadmium in the fourth quarter sample is $<1.39 \mathrm{mg} / \mathrm{L}$. To be conservative, one can assume the detection limit is the value, 1.39 $\mathrm{mg} / \mathrm{L} \mathrm{Cd}$. From Figure 2, it can be seen that the saltstone sample is $45.52 \mathrm{wt} \%$ salt solution. Reference ${ }^{7}$ reports a specific gravity of 1.22 .

$\frac{m g C d}{\mathrm{~kg} \text { saltstone }}=\frac{1.39 \mathrm{mgCd}}{L \text { salt solution }} \times \frac{1 \mathrm{~L} \text { salt solution }}{1.22 \mathrm{~kg} \text { salt solution }} \times \frac{0.4552 \mathrm{~kg} \text { salt solution }}{1 \mathrm{~kg} \text { saltstone }}=0.52$

In the TCLP, the saltstone is extracted by a $20 \mathrm{x}$ mass of extraction fluid. ${ }^{2}$ When the extraction is complete, the regulatory limits are applied to the concentration of the contaminant in the analysis of the extract solution. Continuing the example, 100 grams of saltstone-containing $0.052 \mathrm{mg}$ cadmium - is extracted by $2 \mathrm{~L}$ of TCLP extract. If all of the cadmium is extracted, the cadmium concentration in the extract would be $0.026 \mathrm{mg} \mathrm{Cd} / \mathrm{L}$ extract. The regulatory limit for cadmium in Table 1 is $1 \mathrm{mg} \mathrm{Cd} / \mathrm{L}$ extract. Therefore, it can be demonstrated without analysis that saltstone prepared for the fourth quarter of CY07 is not hazardous for cadmium. Using this methodology, it can be determined that the saltstone prepared with the salt solutions in Table 1 that the only contaminant that cannot be mathematically excluded from analysis for each sample is mercury. 
WSRC-STI-2008-00260

Revision 0

Saltstone Mix Data Sheet

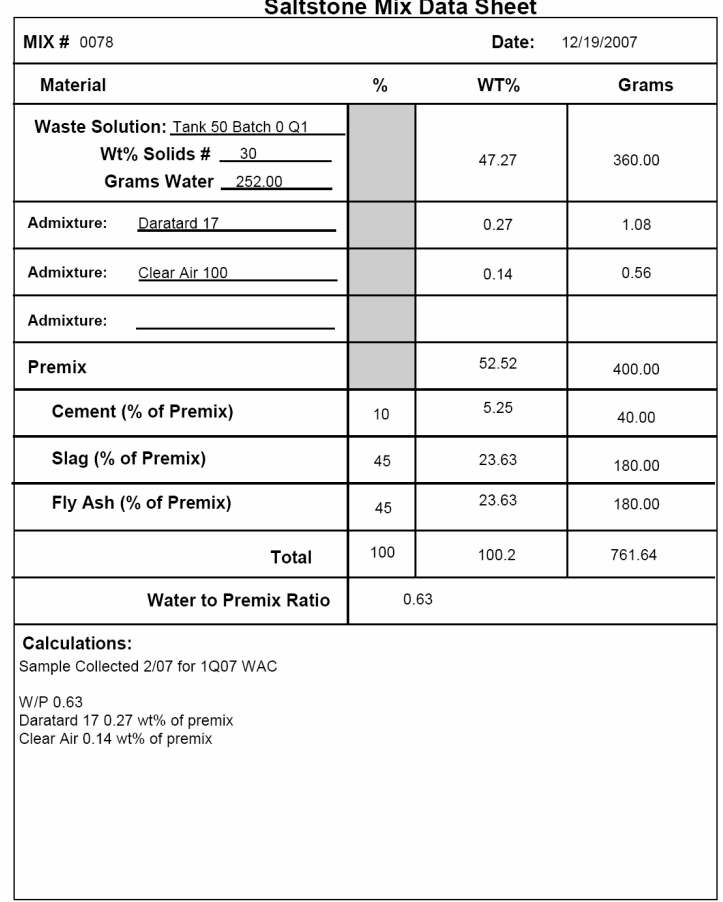

\begin{tabular}{|c|c|c|c|}
\hline \multicolumn{2}{|l|}{ MIX \# 0079} & \multicolumn{2}{|c|}{ Date: $\quad 12 / 19 / 2007$} \\
\hline Material & $\%$ & WT\% & Grams \\
\hline $\begin{array}{l}\text { Waste Solution: Tank } 50 \text { Batch } 1 \text { Q2 } \\
\text { Wt } \% \text { Solids \# } \frac{30.45}{253.86} \\
\text { Grams Water }\end{array}$ & & 47.61 & 365.00 \\
\hline Admixture: $\quad$ Daratard 17 & & 0.27 & 1.08 \\
\hline Admixture: $\quad$ Clear Air 100 & & 0.14 & 0.56 \\
\hline Admixture: & & & \\
\hline Premix & & 52.18 & 400.00 \\
\hline Cement (\% of Premix) & 10 & 5.22 & 40.00 \\
\hline Slag (\% of Premix) & 45 & 23.48 & 180.00 \\
\hline Fly Ash (\% of Premix) & 45 & 23.48 & 180.00 \\
\hline Total & 100 & 100.2 & 766.64 \\
\hline Water to Premix Ratio & \multicolumn{3}{|c|}{0.63} \\
\hline \multicolumn{4}{|l|}{$\begin{array}{l}\text { Calculations: } \\
\text { wt } \% \text { solids from TK } 50 \text { WAC for 4/07 samples }\end{array}$} \\
\hline
\end{tabular}

Saltstone Mix Data Sheet

\begin{tabular}{|c|c|c|c|}
\hline \multicolumn{4}{|c|}{ Saltstone Mix Data Sheet } \\
\hline \multicolumn{2}{|l|}{ MIX \# 0080} & \multicolumn{2}{|c|}{ Date: $\quad 12 / 19 / 2007$} \\
\hline Material & $\%$ & WT\% & Grams \\
\hline Waste Solution: Tank 50 Batch $2 \mathrm{Q} 3$ & & & \\
\hline Wt $\%$ Solids \# 27.4 & & 45.86 & 340.00 \\
\hline Grams Water 246.84 & & & \\
\hline Admixture: $\quad$ Daratard 17 & & 0.27 & 1.08 \\
\hline Admixture: $\quad$ Clear Air 100 & & 0.07 & 0.26 \\
\hline \multicolumn{4}{|l|}{ Admixture: } \\
\hline Premix & & 53.96 & 400.00 \\
\hline Cement ( $\%$ of Premix) & 10 & 5.40 & 40.00 \\
\hline Slag (\% of Premix) & 45 & 24.28 & 180.00 \\
\hline Fly Ash (\% of Premix) & 45 & 24.28 & 180.00 \\
\hline Total & 100 & 100.2 & 741.34 \\
\hline Water to Premix Ratio & \multicolumn{3}{|c|}{0.62} \\
\hline \multicolumn{4}{|l|}{$\begin{array}{l}\text { Calculations: } \\
\text { wt } \% \text { solids from TK } 50 \text { WAC for } 9 / 07 \text { samples }\end{array}$} \\
\hline \multicolumn{4}{|l|}{$\begin{array}{l}\text { Per LWO-WSE-2007-00216 } \\
\text { W/P 0.62 } \\
\text { Daratard } 170.27 \text { wt } \% \text { of premix } \\
\text { Clear Air } 0.066 \text { wt } \% \text { of premix }\end{array}$} \\
\hline
\end{tabular}

Saltstone Mix Data Sheet

\begin{tabular}{|c|c|c|c|}
\hline \multicolumn{4}{|c|}{ Saltstone Mix Data Sheet } \\
\hline \multicolumn{2}{|l|}{ MIX \# 0082} & \multicolumn{2}{|c|}{ Date: $\quad 12 / 19 / 2007$} \\
\hline Material & $\%$ & WT\% & Grams \\
\hline $\begin{array}{l}\text { Waste Solution: Tank 50 Batch } 2 \text { Q4 } \\
\text { Wt } \% \text { Solids \# } \frac{26.2}{247.23} \\
\text { Grams Water }\end{array}$ & & 45.52 & 335.00 \\
\hline Admixture: $\quad$ Daratard 17 & & 0.19 & 0.75 \\
\hline Admixture: $\quad$ Clear Air 100 & & 0.07 & 0.26 \\
\hline Admixture: & & & \\
\hline Premix & & 54.35 & 400.00 \\
\hline Cement (\% of Premix) & 10 & 5.43 & 40.00 \\
\hline Slag (\% of Premix) & 45 & 24.46 & 180.00 \\
\hline Fly Ash (\% of Premix) & 45 & 24.46 & 180.00 \\
\hline Total & 100 & 100.1 & 736.01 \\
\hline Water to Premix Ratio & & & \\
\hline $\begin{array}{l}\text { Calculations: } \\
\text { wt \% solids from TK } 50 \text { WAC for } 11 / 07 \text { sample } \\
\text { Per LWO-WSE-2007-00216 } \\
\text { W/P } 0.62 \\
\text { Daratard } 170.19 \text { wt } \% \text { of premix } \\
\text { Clear Air } 0.066 \text { wt } \% \text { of premix }\end{array}$ & & & \\
\hline
\end{tabular}

Figure 2. Data sheets for the saltstone mixes used to prepare samples for TCLP. 
WSRC-STI-2008-00260

Revision 0

\subsection{Saltstone Testing}

Saltstone testing was performed by B\&WTSG-RACL and GEL Laboratories, LLC. Activities associated with the four $\mathrm{CY} 07$ saltstone samples were:

\section{At B\&WTSG-RACL,}

- performing the TCLP extraction,

- digesting the TCLP leachate,

- analyzing the digested leachate.

At GEL

- performing extractions on solid subsamples shipped from B\&WTSG-RACL,

- analyzing extracts.

\subsubsection{B\&WTSG-RACL}

The samples arrived at B\&WTSG-RACL, Lynchburg, Virginia on March 17, 2008 for analysis. Shipping container temperatures were documented to be within specifications. The samples were delivered with proper chain of custody documentation and signatures. All sample containers arrived without any visible signs of tampering or breakage.

The Metals method 6020A analysis was performed on an X-7 Series Inductively Coupled Plasma - Mass Spectrometer (ICP-MS). The instrument measures ions produced by a radio-frequency inductively coupled plasma. Analyte species originating in a liquid are nebulized and the resulting aerosol transported by argon gas into the plasma torch. The ions produced by high temperatures are entrained in the plasma gas and introduced, by means of an interface, into a mass spectrometer. The ions produced in the plasma are sorted according to their mass-to-charge rations and quantified with a channel electron multiplier. Mass interferences must be assessed and valid corrections applied or the data flagged to indicate problems.

The Metals method 7470A analysis was performed on a Leman PC 200 II instrument which consists of a cold vapor atomic absorption spectrometer (CVAA) set to detect mercury at a wavelength of $253.7 \mathrm{~nm}$. The mercury is reduced to the elemental state and aerated from solution in a closed system. The mercury vapor passes through a cell positioned in the light path of an atomic absorption spectrophotometer. Absorbance (peak height) is measured as a function of mercury concentration.

A portion of the leachate from the first quarter sample was used as the quality control sample (matrix spike) for the ICP-MS and CVAA.

\subsubsection{GEL Laboratories, LLC}

The subsamples arrived at GEL Laboratories, LLC, Charleston, South Carolina on March 20, 2008 for analysis. Shipping container temperatures were documented to be within specifications. The samples were delivered with proper chain of custody documentation and signatures. All sample containers arrived without any visible signs of tampering or breakage.

The method 8260B analysis was performed with an HP6890/HP5973 gas chromatograph/mass spectrometer using an Agilent DB-624 column.

The methods 9012A and 9066 were performed using a Lachat QuickChem FIA+ Ion Analyzer. 


\subsection{RESULTS \& DISCUSSION}

\subsection{Sample Results}

Results were summarized in Table 3 from the data package for these analyses. ${ }^{9}$ Data is presented as reported by the vendors.

\subsubsection{B\&WTSG-RACL}

Analytes detected but at concentrations too low to determine quantitatively have been flagged with the "J" qualifier. Analytes that were not detected have been flagged with the "U" qualifier. In addition to the results, Detection Limits (DLs) have been given. The DL is the minimum concentration of an analyte that can be identified, measured, and reported with $99 \%$ confidence that the concentration is above zero. The DL values given in the table are the results from this study adjusted for sample dilution. The QL is the lowest level at which an analyte may be accurately and reproducibly quantitated.

Results in Table 3, when compared with the DLs and QLs, can be organized into three groups:

- Cadmium, silver, and beryllium were not detected in any leachates.

- Chromium, lead, selenium, nickel, and thallium were detected below the QLs.

- Arsenic, barium and mercury were detected in all leachates at concentrations above the QLs.

Table 3. TCLP Leachates RCRA Metal Concentrations, DLs, and QLs.

\begin{tabular}{|c|c|c|c|c|c|c|c|}
\hline - & Methods & $\begin{array}{l}\text { Sample } \\
\text { Limits }\end{array}$ & $\begin{array}{l}\text { Sample } \\
\text { Limits }\end{array}$ & \multicolumn{4}{|c|}{ Sample Results $(\mu \mathrm{g} / \mathrm{L})$} \\
\hline SRS ID & - & - & - & 1Q07 & 2Q07 & 3Q07 & 4Q07 \\
\hline B\&W ID & - & DL & QL & 0803011-01 & 0803011-02 & 0803011-03 & 0803011-04 \\
\hline As & $3015 \mathrm{~A}, 6020 \mathrm{~A}$ & 0.100 & 5.556 & 16.8 & 15.0 & 18.1 & 16.5 \\
\hline $\mathbf{B a}$ & $3015 \mathrm{~A}, 6020 \mathrm{~A}$ & 0.439 & 55.556 & 168 & 186 & 177 & 187 \\
\hline Cd & $3015 \mathrm{~A}, 6020 \mathrm{~A}$ & 0.111 & 5.556 & $\overline{\mathrm{U}_{0}} 0.111$ & ${ }^{\mathrm{U}} 0.111$ & $\overline{\mathrm{U}_{0}} 0.111$ & $\overline{\mathrm{U}_{0}} 0.111$ \\
\hline $\mathrm{Cr}$ & $3015 \mathrm{~A}, 6020 \mathrm{~A}$ & 0.306 & 11.111 & 6.8 & 4.9 & 5.6 & 5.5 \\
\hline $\mathbf{P b}$ & $3015 \mathrm{~A}, 6020 \mathrm{~A}$ & 0.483 & 5.556 & 2.6 & $\mathrm{U}_{0.483}$ & $\mathrm{U}_{0.483}$ & $\mathrm{U}_{0.483}$ \\
\hline $\mathbf{H g}$ & $7470 \mathrm{~A}$ & 0.068 & 0.200 & 2.510 & 6.740 & 3.920 & 5.000 \\
\hline Se & $3015 \mathrm{~A}, 6020 \mathrm{~A}$ & 0.244 & 27.778 & 8.9 & 8.6 & 10.3 & 7.9 \\
\hline Ag & $3015 \mathrm{~A}, 6020 \mathrm{~A}$ & 0.061 & 5.556 & ${ }^{\mathrm{U}} 0.061$ & $\mathrm{U}_{0.061}$ & ${ }^{\mathrm{U}} 0.061$ & $\mathrm{U}_{0.061}$ \\
\hline $\mathbf{B e}$ & $3015 \mathrm{~A}, 6020 \mathrm{~A}$ & 0.156 & 5.556 & ${ }^{\mathrm{U}} 0.156$ & ${ }^{\mathrm{U}} 0.156$ & ${ }^{\mathrm{U}} 0.156$ & ${ }^{\mathrm{U}} 0.156$ \\
\hline $\mathbf{N i}$ & $3015 \mathrm{~A}, 6020 \mathrm{~A}$ & 1.6 & 5.556 & 3.7 & 3.9 & 3.0 & 3.3 \\
\hline Tl & $3015 \mathrm{~A}, 6020 \mathrm{~A}$ & 0.206 & 5.556 & ${ }^{\mathrm{B}} 0.483$ & 3.4 & ${ }^{\mathrm{B}} 1.4$ & ${ }^{\mathrm{B}} 0.817$ \\
\hline
\end{tabular}

- Indicates a location in the table for which an entry would not be appropriate.

${ }^{\mathrm{U}}$ Final concentration of the analyte was found to be below the DL.

${ }^{B}$ Analyte is present at a concentration above the DL but less than the QL.

\subsubsection{Comparison of Results to Regulatory Limits}

Results from the TCLP leachate analyses from Table 3 are replicated in Table 4 -with units changed from $\mu \mathrm{g} / \mathrm{L}$ to $\mathrm{mg} / \mathrm{L}$ - along with the regulatory limits that may be applied to the Saltstone waste form. Table 4 includes the SCHWMR R.61-79.261.24(b) limits above which a waste is to be considered characteristically hazardous for toxicity and the SCHWMR R.61- 
79.268.48 Universal Treatment Standards (UTS) for hazardous constituents. In addition, Maximum Contaminant Levels (MCLs) from the State Primary Drinking Water Regulations ${ }^{\dagger}$ also have been included in Table 4. By comparing the sample results and the regulatory limits in Table 4, the following conclusions can be made:

- The saltstone waste form was not characteristically hazardous for toxicity.

- The leachate metals concentrations were below the Nonwastewater Standard for all of the metals.

- The leachate metals concentrations were below the MCLs for barium, cadmium, chromium, lead, selenium, silver and thallium - except for the 2Q07 sample. Nickel does not have an MCL value.

- Arsenic and mercury exceeded the MCL in all samples. Thallium exceeded the MCL in the 2Q07 sample. The MCL is the limit for a constituent in drinking water. The MCL is used to determine the class of landfill required. At 10x MCL, a Class 3 landfill is required. The SDF vaults are permitted as a Class 3 landfill.

The TCLP leachate RCRA metal concentrations were well below the SCHWMR R.6179.261.24(b) limits for characteristically hazardous toxic waste. Similarly, all results were less than the UTS Nonwastewater Standard. None of the analyses were greater than $5 \mathrm{x}$ the MCL.

Table 4 Saltstone TCLP Results and Corresponding Regulatory Limits.

\begin{tabular}{|c|c|c|c|c|c|c|c|}
\hline - & \multicolumn{4}{|c|}{ Sample Results (mg/L) } & \multicolumn{3}{|c|}{ Regulatory Limits } \\
\hline SRS ID & $1 Q 07$ & $2 Q 07$ & $3 Q 07$ & $4 Q 07$ & Toxicity $^{a}$ & $\mathbf{U T S}^{\mathbf{b}}$ & MCL $^{\mathrm{c}}$ \\
\hline B\&W ID & $\begin{array}{c}0803011 \\
-01\end{array}$ & $\begin{array}{c}0803011 \\
-02\end{array}$ & $\begin{array}{c}0803011 \\
-03\end{array}$ & $\begin{array}{c}0803011 \\
-04\end{array}$ & $(\mathrm{mg} / \mathrm{L})$ & $\begin{array}{c}\text { Nonwastewater } \\
\text { Standard } \\
\text { (mg/L TCLP) }\end{array}$ & $(\mathrm{mg} / \mathrm{L})$ \\
\hline As & 0.0168 & 0.0150 & 0.0181 & 0.0165 & 5 & 5 & 0.010 \\
\hline $\mathbf{B a}$ & 0.168 & 0.186 & 0.177 & 0.187 & 100 & 21 & 2 \\
\hline $\mathbf{C d}$ & ${ }^{\mathrm{U}} 1 . \mathrm{E}-04$ & ${ }^{\mathrm{U}} 1 . \mathrm{E}-04$ & ${ }^{\mathrm{U}} 1 . \mathrm{E}-04$ & ${ }^{\mathrm{U}} 1 . \mathrm{E}-04$ & 1 & 0.11 & 0.005 \\
\hline $\mathrm{Cr}$ & B $6.8 \mathrm{E}-03$ & ${ }^{\mathrm{B}} 4.9 \mathrm{E}-03$ & ${ }^{\mathrm{B}} 5.6 \mathrm{E}-03$ & ${ }^{\mathrm{B}} 5.5 \mathrm{E}-03$ & 5 & 0.6 & 0.1 \\
\hline $\mathbf{P b}$ & B $2.6 \mathrm{E}-03$ & $\mathrm{U}_{4.83 \mathrm{E}-04}$ & $\mathrm{U}_{4.83 \mathrm{E}-04}$ & $\overline{\mathrm{U}} 4.83 \mathrm{E}-04$ & 5 & 0.75 & $0.015^{\mathrm{d}}$ \\
\hline $\mathrm{Hg}$ & $2.5 \mathrm{E}-03$ & $6.7 \mathrm{E}-03$ & $3.9 \mathrm{E}-03$ & $5.0 \mathrm{E}-03$ & 0.2 & 0.025 & $2 \mathrm{E}-03$ \\
\hline Se & B $8.9 \mathrm{E}-03$ & ${ }^{\mathrm{B}} 8.6 \mathrm{E}-03$ & ${ }^{\mathrm{B}} 1.0 \mathrm{E}-02$ & B 7.9E-03 & 1 & 5.7 & 0.05 \\
\hline Ag & $\mathrm{U}_{6.1 \mathrm{E}-05}$ & ${ }^{\mathrm{U}} 6.1 \mathrm{E}-05$ & ${ }^{\mathrm{U}} 6.1 \mathrm{E}-05$ & $\mathrm{U}_{6.1 \mathrm{E}-05}$ & 5 & 0.14 & $0.1^{\mathrm{e}}$ \\
\hline Be & $\mathrm{U}_{1} 1.6 \mathrm{E}-04$ & ${ }^{\mathrm{U}} 1.6 \mathrm{E}-04$ & ${ }^{\mathrm{U}} 1.6 \mathrm{E}-04$ & ${ }^{\mathrm{U}} 1.6 \mathrm{E}-04$ & - & 1.22 & 4E-03 \\
\hline $\mathbf{N i}$ & B3.7E-03 & B $3.9 \mathrm{E}-03$ & B $3.0 \mathrm{E}-03$ & B 3.3E-03 & - & 11 & - \\
\hline Tl & B $4.8 \mathrm{E}-04$ & B $3.4 \mathrm{E}-03$ & ${ }^{\mathrm{B}} 1.4 \mathrm{E}-03$ & B $8.2 \mathrm{E}-04$ & - & 0.20 & $2 \mathrm{E}-03$ \\
\hline
\end{tabular}

- Indicates a location in the table for which an entry would not be appropriate.

${ }^{\mathrm{U}}$ Final concentration of the analyte was found to be below the DL.

${ }^{\mathrm{B}}$ Analyte is present at a concentration above the DL but less than the QL.

${ }^{a}$ R.61-79.261.24(b) "Characteristic of Toxicity".

${ }^{\mathrm{b}}$ R.61-79.268.48 "Universal Treatment Standards".

${ }^{\text {c }}$ SCDHEC State Primary Drinking Water Regulation Maximum Contaminant Levels.

${ }^{\mathrm{d}}$ Lead action level from SCDHEC 61-58.11.B.

${ }^{\mathrm{e}}$ Secondary drinking water parameter.

\footnotetext{
${ }^{\dagger}$ Regulations 61-58 through 61-58.15 are promulgated pursuant to S.C. Code Sections 44-55-10 et seq. and are collectively known as the State Primary Drinking Water Regulations.
} 


\subsubsection{Quality Assurance}

The following subsections include summaries of results from blanks, laboratory control samples, matrix spikes, and matrix spike duplicates. The data package for this task also includes data for calibration verifications, interference checks, and serial dilutions.

\subsubsection{Blanks}

Blank concentrations are given in Table 5. In the Method Blank, arsenic, lead, selenium and nickel were present at levels above their DLs, but below their QLs. In the TCLP Blank, barium, chromium, lead, selenium, silver, nickel and thallium were present at levels above their DLs, but below their QLs. The Method Blanks analyzed with this Sample Delivery Group (SDG) met the acceptance criteria. Nickel is of the same magnitude in both blanks and in the quarterly samples. This suggests that the vendor is experiencing difficulty with measuring nickel in their systemeither the Torch is producing a high background level of nickel, or there is a mass interference with this measurement.

Table 5. Method Blank and TCLP Blank.

\begin{tabular}{|c||c||c|}
\hline \hline Analyte & Method Blank $(\mu \mathrm{g} / \mathrm{L})$ & TCLP Blank $(\mu \mathrm{g} / \mathrm{L})$ \\
\hline \hline $\mathbf{A s}$ & ${ }^{\mathrm{B}}-0.111$ & ${ }^{\mathrm{U}} 0.100$ \\
\hline $\mathbf{B a}$ & ${ }^{\mathrm{U}} 0.439$ & ${ }^{\mathrm{B}} 9.5$ \\
\hline $\mathbf{C d}$ & ${ }^{\mathrm{U}} 0.111$ & ${ }^{\mathrm{U}} 0.111$ \\
\hline $\mathbf{C r}$ & ${ }^{\mathrm{U}} 0.306$ & ${ }^{\mathrm{B}} 5.38$ \\
\hline $\mathbf{P b}$ & ${ }^{\mathrm{B}} 0.606$ & ${ }^{\mathrm{B}} 1.3$ \\
\hline $\mathbf{H g}$ & ${ }^{\mathrm{U}} 0.068$ & ${ }^{\mathrm{U}} 0.068$ \\
\hline $\mathbf{S e}$ & ${ }^{\mathrm{B}} 1.978$ & ${ }^{\mathrm{B}} 1.3$ \\
\hline $\mathbf{A g}$ & ${ }^{\mathrm{U}} 0.061$ & ${ }^{\mathrm{B}} 0.128$ \\
\hline $\mathbf{B e}$ & ${ }^{\mathrm{U}} 0.156$ & ${ }^{\mathrm{U}} 0.156$ \\
\hline $\mathbf{N i}$ & ${ }^{\mathrm{B}} 3.106$ & ${ }^{\mathrm{B}} 4.5$ \\
\hline $\mathbf{T l}$ & ${ }^{\mathrm{U}} 0.206$ & ${ }^{\mathrm{B}} 0.828$ \\
\hline
\end{tabular}

${ }^{\mathrm{U}}$ Final concentration of the analyte was found to be below the DL.

${ }^{\mathrm{B}}$ Analyte is present at a concentration above the DL but less than the QL.

\subsubsection{Laboratory Control Samples}

Results from the Laboratory Control Sample (LCS) are given in Table 6. All LCS recoveries except selenium met USEPA SW-846 acceptance limits (85-125\% recovery). Laboratory Control Samples are clean aqueous solutions analyzed to assure integrity of the analytical technique exclusive of matrix effects. 
WSRC-STI-2008-00260

Revision 0

Table 6. RCRA Metal Laboratory Control Sample.

\begin{tabular}{|c||c|c||c||}
\hline \multirow{2}{*}{ Analyte } & \multicolumn{2}{|c||}{$\begin{array}{c}\text { Laboratory Control } \\
(\mu \mathbf{g} / \mathbf{L})\end{array}$} & Recovery (\%) \\
\hline- & True & Measured & - \\
\hline \hline $\mathbf{A s}$ & 755.0 & 646.11 & 86 \\
\hline $\mathbf{B a}$ & 2180.0 & 2030.0 & 93 \\
\hline $\mathbf{C d}$ & 112.0 & 102.44 & 91 \\
\hline $\mathbf{C r}$ & 417.0 & 396.56 & 95 \\
\hline $\mathbf{P b}$ & 1630.0 & 1562.22 & 96 \\
\hline $\mathbf{H g}$ & 8.4 & 9.78 & 116.3 \\
\hline $\mathbf{S e}$ & 502.0 & 391.22 & 78 \\
\hline $\mathbf{A g}$ & 574.0 & 547.78 & 95 \\
\hline $\mathbf{B e}$ & 629.0 & 581.11 & 92 \\
\hline $\mathbf{N i}$ & 843.0 & 789.44 & 94 \\
\hline $\mathbf{T l}$ & 445.0 & 408.61 & 92 \\
\hline
\end{tabular}

\subsubsection{Matrix Spikes}

Results from analysis of the matrix spike (MS) and matrix spike duplicates (MSD) are given in Table 7. These results show that:

- The percent recoveries $(\% \mathrm{R})$ obtained from the MS analyses met the recommended quality control acceptance criteria for percent recoveries for all applicable analytes with the exceptions of silver, nickel, selenium, and cadmium.

- The percent recoveries (\%R) obtained from the MSD analyses met the recommended quality control acceptance criteria for percent recoveries for all applicable analytes with the exceptions of silver, nickel, selenium, and cadmium.

- The RPD(s) between the MS and MSD met the acceptance limits. 
WSRC-STI-2008-00260

Revision 0

Table 7. TCLP Leachates RCRA Metal Matrix Spike and Duplicate Results.

\begin{tabular}{|c|c|c|c|c|c|c|c|}
\hline Analyte & $\begin{array}{r}\text { Initial Col } \\
(\mu\end{array}$ & ntrations & $\begin{array}{r}\text { Spiked } \\
(\mu \xi\end{array}$ & $\begin{array}{l}\text { Sample } \\
\text { /L) }\end{array}$ & Recc & ery $(\%)$ & $\begin{array}{l}\text { RPD } \\
(\%)\end{array}$ \\
\hline - & $\begin{array}{c}\text { B\&W ID } \\
\text { 08037-SS- } \\
\text { 07FY01 } \\
\end{array}$ & $\begin{array}{l}\text { Spike } \\
\text { Added }\end{array}$ & Spike & $\begin{array}{c}\text { Spike } \\
\text { Duplicate }\end{array}$ & Spike & $\begin{array}{c}\text { Spike } \\
\text { Duplicate }\end{array}$ & - \\
\hline As & 16.8 & 2222.22 & 1741.6667 & 1692.7779 & 78 & 76 & 3 \\
\hline $\mathbf{B a}$ & 168 & 2222.22 & 2035.0000 & 2057.7779 & 90 & 91 & 1 \\
\hline Cd & $\mathrm{U}_{0.111}$ & 55.56 & 40.8556 & 41.3722 & 74 & 74 & 1 \\
\hline $\mathrm{Cr}$ & ${ }^{\mathrm{B}} 6.8$ & 222.22 & 180.2778 & 183.8333 & 81 & 82 & 2 \\
\hline $\mathbf{P b}$ & B2.6 & 555.56 & 490.3889 & 503.5000 & 88 & 91 & 3 \\
\hline $\mathrm{Hg}$ & 2.510 & 5.0 & 7.900 & 7.960 & 107.8 & 109 & 0.8 \\
\hline Se & B 8.9 & 2222.22 & 1565.5554 & 1445.5556 & 70 & 65 & 8 \\
\hline Ag & ${ }^{\mathrm{U}_{0.061}}$ & 55.56 & 11.8222 & 11.8167 & 21 & 21 & 0 \\
\hline Be & ${ }^{\mathrm{U}} 0.156$ & 55.56 & 44.6944 & 45.8500 & 80 & 83 & 3 \\
\hline $\mathbf{N i}$ & $\mathrm{B}_{3.7}$ & 555.56 & 401.7222 & 410.5000 & 72 & 74 & 2 \\
\hline Tl & ${ }^{\mathrm{B}} 0.483$ & 2222.22 & 2003.3333 & 2061.1112 & 90 & 93 & 3 \\
\hline
\end{tabular}

${ }^{\mathrm{U}}$ Final concentration of the analyte was found to be below the DL.

${ }^{\mathrm{B}}$ Analyte is present at a concentration above the DL but less than the QL.

\subsubsection{Calibration Information}

- All initial calibration requirements have been met for this sample delivery group (SDG).

- All Contract Required Detection Limit standard(s) met the referenced advisory control limits.

- All interference check samples associated with this SDG met the established acceptance criteria.

- All continuing calibration blanks bracketing this batch met the established acceptance criteria.

- All continuing calibration verifications bracketing this SDG met the acceptance criteria.

\subsubsection{GEL Laboratories, LLC}

Analytes detected but at concentrations too low to determine quantitatively have been flagged with the "J" qualifier. Analytes that were not detected have been flagged with the "U" qualifier. In addition to the results, Detection Limits (DLs) and Reporting Limits (RLs) have been given. The DL is the minimum concentration of an analyte that can be identified, measured, and reported with $99 \%$ confidence that the concentration is above zero. The DL values given in Table 8 are the results from this study adjusted for sample dilution. The RL is the lowest level at which an analyte may be accurately and reproducibly quantitated. 
WSRC-STI-2008-00260

Revision 0

Table 8. Totals Concentrations, DLs, and RLs.

\begin{tabular}{|c|c|c|c|c|c|c|c|}
\hline - & Methods & $\begin{array}{c}\text { Sample } \\
\text { Limits }\end{array}$ & $\begin{array}{c}\text { Sample } \\
\text { Limits }\end{array}$ & \multicolumn{4}{|c|}{ Sample Results $(\mu \mathrm{g} / \mathrm{kg})$} \\
\hline SRS ID & - & - & - & $1 \mathrm{Q07}$ & 2Q07 & 3Q07 & 4Q07 \\
\hline GEL ID & - & DL & $\mathbf{R L}$ & 205116001 & 205116002 & 205116003 & 205116004 \\
\hline benzene & 5030B, 8260B & 1.65 & 5.00 & $\mathrm{U}_{5.00}$ & $\mathrm{~J}_{3.30}$ & $\mathrm{~J} 3.38$ & 9.93 \\
\hline phenol & $9010 \mathrm{~B}, 9066$ & 72.1 & 240 & ${ }^{\mathrm{U}} \mathrm{ND}$ & ${ }^{\mathrm{J}} 217$ & ${ }^{\mathrm{J}} 174$ & ${ }^{\mathrm{U}} \mathrm{ND}$ \\
\hline $\begin{array}{c}\text { cyanide } \\
\text { (total) }\end{array}$ & $9010 \mathrm{~B}, 9012 \mathrm{~A}$ & 63.7 & 236 & 5610 & 5050 & 5540 & 5320 \\
\hline $\begin{array}{c}\text { cyanide } \\
\text { (amenable) }\end{array}$ & $9012 \mathrm{~A}$ & 63.7 & 236 & ${ }^{\mathrm{U}} \mathrm{ND}$ & 1280 & ${ }^{\mathrm{U}} \mathrm{ND}$ & 630 \\
\hline
\end{tabular}

- Indicates a location in the table for which an entry would not be appropriate.

ND - Not Detectable

${ }^{\mathrm{U}}$ Final concentration of the analyte was found to be below the DL.

${ }^{\mathrm{J}}$ Analyte is present at a concentration above the DL but less than the RL.

\subsubsection{Comparison of Results to Regulatory Limits}

Results from the analyses from Table 8 are replicated in Table 9-with units changed from $\mu \mathrm{g} / \mathrm{kg}$ to $\mathrm{mg} / \mathrm{kg}$ - along with the regulatory limits that may be applied to the Saltstone waste form. Table 9 includes the SCHWMR R.61-79.268.48 Universal Treatment Standards (UTS) for hazardous constituents. By comparing the sample results and the regulatory limits in Table 9, the following conclusions can be made:

- The totals concentrations were below the Nonwastewater Standard for all of the analytes.

Table 9 Saltstone Totals Results and Corresponding Regulatory Limits.

\begin{tabular}{||c||c|c|c|c||c||}
\hline \multicolumn{1}{|c||}{} & \multicolumn{4}{c||}{$\begin{array}{c}\text { Sample Results } \\
\text { (mg/kg) }\end{array}$} & $\begin{array}{c}\text { Regulatory Limits } \\
\text { (mg/kg) }\end{array}$ \\
\hline SRS ID & $\mathbf{1 Q 0 7}$ & $\mathbf{2 Q 0 7}$ & $\mathbf{3 Q 0 7}$ & $\mathbf{4 Q 0 7}$ & \multirow{2}{*}{ UTS $^{\mathbf{b}}$} \\
\hline GEL ID & $\mathbf{2 0 5 1 1 6 0 0 1}$ & $\mathbf{2 0 5 1 1 6 0 0 2}$ & $\mathbf{2 0 5 1 1 6 0 0 3}$ & $\mathbf{2 0 5 1 1 6 0 0 4}$ & \\
\hline benzene & ${ }^{\mathrm{U}} 0.00500$ & ${ }^{\mathrm{J}} 0.00330$ & ${ }^{\mathrm{J}} 0.00338$ & 0.00993 & 10 \\
\hline phenol & ${ }^{\mathrm{U}} \mathrm{ND}$ & ${ }^{\mathrm{J}} 0.217$ & ${ }^{\mathrm{J}} 0.174$ & ${ }^{\mathrm{U}} \mathrm{ND}$ & 6.2 \\
\hline cyanide (total) & 5.610 & 5.050 & 5.540 & 5.320 & 590 \\
\hline cyanide (amenable) & ${ }^{\mathrm{U}} \mathrm{ND}$ & 0.1280 & ${ }^{\mathrm{U}} \mathrm{ND}$ & 0.630 & 30 \\
\hline \hline
\end{tabular}

- Indicates a location in the table for which an entry would not be appropriate.

${ }^{\mathrm{U}}$ Final concentration of the analyte was found to be below the DL.

${ }^{\mathrm{B}}$ Analyte is present at a concentration above the DL but less than the QL.

${ }^{\mathrm{b}}$ R.61-79.268.48 "Universal Treatment Standards".

\subsubsection{Quality Assurance}

The following subsections include summaries of results from blanks, laboratory control samples, matrix spikes, and matrix spike duplicates. The data package for this task also includes data for calibration verifications, interference checks, and serial dilutions.

\subsubsection{Blanks}

Blank concentrations are given in Table 10. No analytes were detected in the Method Blank. Amenable to chlorination cyanide is determined by subtracting the results determined in the 
chlorinated cyanide test from those determined in the total cyanide test. The Method Blanks analyzed with this Sample Delivery Group (SDG) met the acceptance criteria.

Table 10. Method Blank.

\begin{tabular}{|c||c||}
\hline Analyte & $\begin{array}{c}\text { Method Blank } \\
(\boldsymbol{\mu g} / \mathbf{k g})\end{array}$ \\
\hline \hline benzene & $\mathrm{U}_{1.0}$ \\
\hline phenol & $\mathrm{U}^{\mathrm{ND}}$ \\
\hline cyanide (total) & $\mathrm{U}^{\mathrm{ND}}$ \\
\hline cyanide (amenable) & ${ }^{--}$ \\
\hline
\end{tabular}

- Indicates a location in the table for which an entry would not be appropriate. ND - Not Detectable

${ }^{\mathrm{U}}$ Final concentration of the analyte was found to be below the DL.

\subsubsection{Laboratory Control Samples}

Results from the Laboratory Control Sample (LCS) are given in Table 11. All LCS recoveries met USEPA SW-846 acceptance limits (85-125\% recovery). Laboratory Control Samples are clean aqueous solutions analyzed to assure integrity of the analytical technique exclusive of matrix effects.

Table 11. Laboratory Control Sample.

\begin{tabular}{|c||c|c|c||c|c||}
\hline \multirow{2}{*}{ Analyte } & \multicolumn{3}{|c||}{$\begin{array}{c}\text { Laboratory Control } \\
(\boldsymbol{\mu g} / \mathbf{k g})\end{array}$} & \multicolumn{2}{|c|}{ Recovery (\%) } \\
\hline- & True & \multicolumn{2}{|c||}{ Measured } & \multicolumn{2}{|c|}{-} \\
\hline \hline benzene & 50.0 & 41.8 & 41.7 & 84 & 83 \\
\hline phenol & 2500 & 2750 & 2490 & 110 & 99 \\
\hline cyanide (total) & 174000 & \multicolumn{2}{|c|}{283000} & \multicolumn{2}{|c|}{$162^{\mathrm{a}}$} \\
\hline cyanide (amenable) & -- & \multicolumn{2}{|c|}{--} & \multicolumn{2}{|c|}{--} \\
\hline
\end{tabular}

${ }^{a}$ The recovery $\%$ for the LCS was outside of the normal acceptance limits. However, the value was within the acceptance criteria.

\subsubsection{Matrix Spikes}

Total cyanide is the only method where a matrix spike would be applicable. The result from analysis of the matrix spike (MS) is given in Table 12. These results show that the percent recoveries $(\% \mathrm{R})$ obtained from the MS analyses met the recommended quality control acceptance criteria for percent recoveries.

Table 12. Matrix Spike Results.

\begin{tabular}{|c|c|c|c|c|}
\hline \multirow{2}{*}{$\begin{array}{c}\text { Analyte } \\
-\end{array}$} & \multicolumn{2}{|c|}{$\begin{array}{c}\text { Initial Concentrations } \\
(\mu \mathrm{g} / \mathrm{kg})\end{array}$} & \multirow{2}{*}{$\begin{array}{l}\text { Spiked Sample } \\
\qquad(\mu \mathrm{g} / \mathrm{kg})\end{array}$} & \multirow{2}{*}{ Recovery (\%) } \\
\hline & $\begin{array}{c}\text { GEL ID } \\
120115411701 \\
\end{array}$ & $\begin{array}{c}\text { Spike } \\
\text { Added }\end{array}$ & & \\
\hline $\begin{array}{c}\text { cyanide } \\
\text { (total) }\end{array}$ & ${ }^{\mathrm{U}} \mathrm{ND}$ & 5520 & 4650 & 84 \\
\hline
\end{tabular}

ND-Not Detectable 


\subsubsection{Calibration Information}

- All initial calibration requirements have been met for this sample delivery group (SDG).

- All Contract Required Detection Limit standard(s) met the referenced advisory control limits.

- All interference check samples associated with this SDG met the established acceptance criteria.

- All continuing calibration blanks bracketing this batch met the established acceptance criteria.

- All continuing calibration verifications bracketing this SDG met the acceptance criteria.

\subsection{CONCLUSIONS}

Preparation of the CY07 saltstone samples and the subsequent TCLP analyses showed that:

- All of saltstone waste form disposed of in the Saltstone Disposal Facility in CY07 was not characteristically hazardous for toxicity.

- The concentrations of the eight RCRA metals and UHCs identified as possible in the saltstone waste form were present at levels below the UTS.

- Analyses met all quality assurance specifications of USEPA SW-846.

The saltstone waste form placed in the Saltstone Disposal Facility in CY07 met the SCHWMR R.61-79.261.24(b) RCRA metals requirements for a nonhazardous waste form. The TCLP leachate concentrations were less than 5x the MCLs in SCDHEC Regulations R.61-107.16, Subpart A, 16.5.

The saltstone waste form placed in the Saltstone Disposal Facility in CY07 met the R.6179.268.48(a) non wastewater treatment standards.

Analyses met all USEPA SW-846 quality assurance requirements. This included limits on holding times, laboratory control sample recoveries, matrix spike recoveries, serial dilution results when applicable, calibration verification, and interference checks. 


\subsection{REFERENCES}

1. Liner, K.R., "Sampling and Analysis Plan for the Z-Area Industrial Solid Waste Landfill Disposal Facility During Interim Salt Waste Processing (U)," ESH-WPG-2005-00039.

2. "Toxicity Characteristic Leaching Procedure," EPA SW-846, Procedure 1311.

3. Britt, T.E., "Assessment of Regulated Organics under 40 CFR Part 268, Section 48, Universal Treatment Standards, Relative to SRS Tank Farm Waste," LWO-LWE-200700052 .

4. Badheka, N.P., "Characterization of Tank 50h Sample Waste -2007," WSRC-TR-200700253, 2/07.

5. Zeigler, K.E., Bibler, N.E., "Characterization of Tank 50 Slurry for Saltstone Waste Acceptance Criteria, April 2007 Samples," WSRC-TR-2007-00554, 4/07.

6. Zeigler, K.E., Bibler, N.E., "Results for the Third Quarter 2007 Tank 50h WAC Slurry Sample: Chemical and Radionuclide Contaminant Results," WSRC-TR-2008-0080, 9/07.

7. Zeigler, K.E., Bibler, N.E., "Results for the Fourth Quarter 2007 Tank 50h WAC Slurry Sample: Chemical Contaminant Results," WSRC-TR-2008-00013, 11/07.

8. Liner, K.R., 11/28/2007, Private Communication.

9. $\quad$ Cozzi, A.D., "Data Package from Vendor for CY07 TCLP Analysis," SRNL-PSE-200800100 . 